\title{
Environmental and legal aspects of sustainable development of the Arctic zone of the Russian Federation using the genomic technologies
}

\author{
N.O. Vedysheva* \\ Federal State Budgetary Educational Institution of Higher Education "Kutafin Moscow State Law \\ University (Moscow State Law Academy)", Sadovaya-Kudrinskaya st., 9, 123001 Moscow, Russia
}

\begin{abstract}
After analyzing the documents of the strategic planning of the Russian Federation, the state policy of the Russian Federation in the Arctic until 2035, the author makes an attempt to consider current legal problems in the field of environmental management and environmental protection in the region, ensuring the sustainable development of the Arctic zone of the Russian Federation. The article highlights the main threats and risks of ensuring the environmental safety, including when applying innovative, genomic technologies in the field of agriculture. In conclusion, a summary is made about the need to amend the legislation of the Russian Federation in terms of ensuring the environmental safety and sustainable development of the Arctic zone of the Russian Federation
\end{abstract}

\section{Introduction}

The sustainable development implies the environmentally sound economic and social development of a society aimed at improving the well-being and protection of the entire planet. In Russian legislation, the concept is implemented through achieving a balance between economic, environmental and social interests of the society [1]. The Sustainable Development Goals formulated by the United Nations in 2015 are implemented in Russian legislation, taking into account the strategic planning (the National Security Strategy of the Russian Federation, the Spatial Development Strategy of the Russian Federation for the period up to 2025, the Economic Security Strategy of the Russian Federation for the period up to 2030, the Environmental Security Strategy of the Russian Federation for the period up to 2025 , etc.)

The sustainable development and development of the Arctic zone of the Russian Federation is implemented through the state policy of the Russian Federation in the Arctic, which among national interests, on the one hand, highlights its development as a strategic resource base, on the other hand, provides for the protection of the environment and protection of the original habitat and traditional nature management of indigenous minorities. From the economic point of view - increasing the volume of geological exploration in the development of deposits of hydrocarbon raw materials and solid minerals; increase in oil and gas recovery factors; creation of conditions for increasing the

\footnotetext{
* Corresponding author: veda120006@yandex.ru
} 
efficiency of development and production (catch) of aquatic biological resources, development of aquaculture; etc. On the environmental side - the development of a network of specially protected natural areas; elimination of accumulated harm to the environment, implementation of a set of measures to exclude the entry of toxic substances, pathogens of infectious diseases into the Arctic, etc. On the third side, social, - the main tasks of state policy are to ensure the availability of medical care, education, services in the field of culture, sports; providing citizens with affordable and high-quality housing, improving the living conditions of people belonging to the minorities, etc. [2]

For the implementation of the sustainable development concept, the indicators (quantitative and qualitative characteristics of sustainable development criteria) and the criteria (strategic directions of practice for the implementation of the principles of sustainable development) are important. Unfortunately, the Fundamentals do not provide target indicators and indicators of environmental sustainable development that characterize the effectiveness of the implementation of the state policy of the Russian Federation in the Arctic.

The study of legal and organizational problems of ensuring the sustainable development, ecological, biological, genetic safety in the Arctic, is reflected in the works of G.V. Vypkhanova. [1], Zhavoronkova N.G. [5], Agafonov V.B., [6] Voronina N.P. [4], Mukhlynina M., Vedysheva N. [1], etc.

\section{Materials and Methods}

The methodological basis of the study was formed by general scientific methods, so the analysis and synthesis were used to study the existing theoretical and methodological approaches and provisions, as well as to conduct scientific research to ensure the environmental safety in the Arctic zone of the Russian Federation.

The informational basis of the study was formed by regulatory legal acts, documents of the state authorities, scientific works on the problems of improving the protection in modern conditions [1], [2], [3]

\section{Results and Discussion}

The foundations of the state policy of the Russian Federation in the Arctic provide for the stimulation of the local production of agricultural raw materials and food. Due to the extreme natural and climatic conditions, the focal nature of industrial and economic development of the territories, low stability of the ecological systems, self-sufficiency in food and biological resources compared to other regions of Russia, is at a low level here. The most promising direction for the development of agriculture in the Arctic zone of the Russian Federation is an innovative way of development, using new biotechnologies, including genomic ones. The use of new technologies "... is focused on the stable development of agricultural production, solving the problem of food security, obtaining high-quality and environmentally friendly food products, recycling agricultural waste, restoring soil fertility" [3]. With the help of Russian genetic technologies, a transition to environmentally friendly agriculture and aquaculture, the rational use of chemical and biological protection of agricultural plants and animals can be ensured. For example, new lines of plants with increased resistance to the harsh climatic conditions of the Arctic, with improved nutritional and technological value, increased shelf life; new lines of farm animals that are resistant to viral diseases (especially in the field of reindeer husbandry) will increase their own agricultural production. 
However, the introduction of new genomic technologies, combined with the climatic changes, potential environmental risks in the field of subsoil use, development of the Northern Sea Route, etc. increase the risks and threats of an agroecological nature, veterinary and phytosanitary risks associated with the emergence and spread of mass infectious animal diseases previously not registered in our territory, the spread of pests and plant diseases. For the Arctic, the main threats will be the risk of degradation of the natural environment and a decrease in its potential, changes in biodiversity, including those associated with the use of genetically modified organisms, as well as disruption of the habitat and traditional use of natural resources of the indigenous minorities.

\section{Conclusion}

The current legislation provides for the stimulation and activation of investment and business activities in the Arctic zone of the Russian Federation [7], but does not provide for the stimulation of the environmental innovations. It seems necessary to consolidate incentive measures for entities carrying out economic activities in the Arctic region for the introduction and use of environmentally friendly and (or) resource-saving technologies focused on a minimum negative impact on the environment, containment and reduction of anthropogenic greenhouse gas emissions.

To identify and consolidate at the legislative level, taking into account the complex environmental monitoring, the threats and environmental risks of certain types of economic and other activities carried out in the Arctic zone of the Russian Federation (consider the possibility of limiting the use of certain technologies); to consolidate legal measures to ensure environmental, biological safety when using genomic technologies.

When adjusting the legislative framework for the Arctic (primarily the natural resource and ecological block), it is necessary to pay attention to the creation of "... an integral ecological and legal system of the international legal level, a new organizational and legal mechanism" [8], to be prepared with the participation of international organizations, the Arctic Council, a document containing a unified approach to ensuring various types of security in the implementation of economic and other activities in the Arctic.

It is necessary to bring the strategic planning documents of the constituent entities of the Russian Federation, municipalities included in the Arctic zone of the Russian Federation into line with the Decree of the President of the Russian Federation "On the national development goals of the Russian Federation for the period up to 2030" [9], with the state policy of the Russian Federation in the Arctic for the period up to 2035, in terms of rational nature management, environmental protection and environmental safety.

Taking into account these proposals, we can talk about the sustainable development of the Arctic zone of the Russian Federation in the interests of the present and future generations.

The study has been carried out with the financial support of the Russian Foundation for Basic Research within the framework of the scientific project No. 18-29-14034

\section{References}

1. G.V. Vypkhanova, Kutafin University (MSAL) Bulletin, 1, 75 (2016); M. Mukhlynina, N. Vedysheva, E3S Web of Conferences. Actual Problems of Ecology and Environmental Management: Cooperation for Sustainable Development and Environmental Safety, 05003 (2020) 
2. Decree of the President of the Russian Federation dated 05.03.2020 No. 164 "On the Fundamentals of State Policy of the Russian Federation in the Arctic for the Period up to 2035", SZ RF. 2020, 10, 1317

3. VP-P8-2322. Comprehensive program for the development of biotechnology in the Russian Federation for the period up to 2020 "(approved by the Government of the Russian Federation 24.04.2012 No. 1853p-P8), SPS "Consultant Plus"

4. N.P. Voronina, Journal of Agriculture and Environment, 3(11), 51 (2019)

5. N.G. Zhavoronkova, Law and modern technologies in medicine: monograph, 249 (2019)

6. V.B. Agafonov, Law and modern technologies in medicine: monograph, 237 (2019)

7. Federal Law of the Russian Federation dated 13.07.2020 No. 193-FZ "On state support for entrepreneurial activity in the Arctic zone of the Russian Federation", SZ RF. 2020, 29, 4503

8. N.G. Zhavoronkova, V.B. Agafonov, Lex Russica, 7, 114 (2018)

9. Decree of the President of the Russian Federation dated July 21, 2020 No. 474 "On the national development goals of the Russian Federation for the period up to 2030" // SZ RF. 2020, 30, 4884 